\title{
The Effect of Monetary Policy on Interest Rates in Turkey: A Microstructural Analysis
}

\author{
Prof. Dr. Muharrem Afsar \\ Faculty of Economics and Administirative Sciences \\ Department of Economics, Anadolu University, Eskisehir, Turkey \\ E-mail: mafsar@anadolu.edu.tr \\ Assoc. Dr. Aslı Afsar \\ Department of Finance, Anadolu University, Eskisehir, Turkey \\ E-mail: aafsar@anadolu.edu.tr \\ Emrah Dogan (Corresponding author) \\ Institute of Social Sciences \\ Department of Economics, Anadolu University, Eskisehir, Turkey \\ E-mail: emrah.dogan@anadolu.edu.tr
}

Received: August 13, 2017 Accepted: September 8, 2017

doi:10.5296/ber.v7i2.11683ＵRL: https://doi.org/10.5296/ber.v7i2.11683

\begin{abstract}
The purpose of this study it to investigate the impact of monetary policy announcements by Central Bank of the Turkish Republic (CBRT) on market interest rates via micro variables on interest rates. In this context, this study investigated the relationship between monetary policy announcements and market interest rates for 2011:01-2015:10 term using GARCH model. The estimates have indicated that monetary policy announcements have different impacts on interest rate volatilities when distinguished as decisions on increasing, decreasing or fixing interest rates. It was found that contractionary monetary policy announcements have different impacts on market interest rates volatilities analyzed in the present study, while expansionary monetary policy announcements decrease the volatility on market interest rates. On the other hand, the announcements towards fixing the monetary policy increases the interest rate
\end{abstract}


volatility of market interest rates. The results of the analysis also indicated that deposit interest rate weighted up to one year are affected the least by the monetary policy changes.

Keywords: Monetary Policy, İnterest Rate, GARCH Model

JEL Classifications: E43, E52, C22

\section{Introduction}

Monetary policy decisions and goals of Central Bank constitute the basis of monetary transmission mechanism and financial system. The communication policy, openness and transparency policies developed by Central Banks in recent years aims to affect the reel economy through investment and consumption decisions of monetary policy decisions. The progresses achieved by Central Banks in the communication policy in recent years have caused considerable changes in the way monetary policy decisions and announcements are perceived by the markets. The fact that decisions taken by the Central Banks about the interests include markets' expectations and how financial markets have reacted to monetary policy decisions has played an important role in the management of economy by taking effective policy decisions and reshaping the expectations.

From the point of policy makers, Central Bank interest rate decisions reflect to what extent interest decisions of the volatility reaction created in the market in response are foreseen and shaped by the markets. On the other hand, from the point of market participants, they play an active role in portfolio optimization and risk management procedures to the extent that decisions taken by financial authority affect the volatilities of the financial assets (Rigobon \& Sack, 2004, p. 1554). Therefore, the dynamic volatility impact process created by the monetary policy announcements of Central Banks plays an important role in their ability to reshape the expectations of market actors and economic units, as well as Central Bank's capability to manage economy with policy interest announcements. Today, as monetary authorities Central Banks implement an effective policy thanks to the policy decisions they take and the information process based on the justification of the relevant decisions. This way, their future projections and goals are transmitted in an open and transparent method. Central Banks notify their policy interest announcements on predetermined dates thanks to the active communication policy in practice and thus aiming to increase the predictability in the markets and decrease the ambiguity.

The purpose of this study is to investigate the impact of policy interest announcements by the CBRT on market interest rates. In this respect, this paper will help the monetary policy decision makers by measuring the volatility permanence time in the CBRT's monetary policy decisions and determine the reaction of market interest rates in response to monetary policy announcements. To this end, in the second phase of the study the possible effects of the Central Bank policy announcements on economy are explained, in the third part the literature review was presented. The fourth part included explanations about the data set used and the GARCH model applied as the method in the study, followed by obtained empirical findings. Last part included evaluation and interpretation of the findings of the study. 


\section{The Effects of Monetary Policy Announcements on Economy}

When Central Banks want to give monetary policy signals, they make decisions on interest rates and make announcements. These announcements have a significant impact on all stock, bond and monetary markets. It is possible to decide whether the monetary policy has consolidated or not in terms of its effects on economy looking at the reactions of market interest rates to monetary policy interest announcements decisions. The first signal of the impact of monetary policy on economy is the emerging change in the short-term interest rate. When the banks and other financial agents change their interest rates, households and companies change their consumption and investment decisions accordingly.

The emerging changes in short term interest rates affect the financial asset prices and shortand long-term reel interest rates which are effective in economic units' decision making processes. This change is reflected on long-term interests based on the expectations regarding the future economy projections. As a result of the change in capital costs, the emerging changes in the prices of the bills affects consumptions through wealth effect and has an impact on investments with Tobin's q effect (Akay \& Nargeleçekenler, 2009, p. 130). Since the bond returns will decrease (increase) as a result of a decrease (increase) in interest by Central Bank, the demand for stocks will increase (decrease) and stock prices will increase (decrease); since domestic reel interest rates will decrease (increase), it will (not) be profitable for portfolio investors to invest in that country, which will cause capital outflow (inflow) from (to) the coutry. As a result of this, the national currency will lose (gain) value, the exchange rates will increase (decrease) and affect the inflation (CBRT, 2013). Manna et al. (2001) suggest that the fluctuations in the interest rates emergent in this transmission process are important indicators of the success of monetary policy.

With the introduction of inflation targeting regime in Turkey in 2005, it was aimed to make monetary policy practices more predictable and transparent (CBRT, 2004). In this respect, since 2005, Monetary Policy board meetings at the hearth of interest decisions started to be held as per a planned schedule. Such that, during the days when interest announcements are done, these days are perceived as important days in markets regarding monetary policy and monitored carefully (Soylu et al., 2014, p. 90).

The global financial crisis experienced in 2008 which caused a strong international financial stress also affected Turkish economy and caused a serious economic recession. In this process Central Bank of the Turkish Republic (CBRT) took an active role in tempering the economic recession with policy interest decisions. In this respect, CBRT decreased the short term interest rates from $16.50 \%$ to $4.50 \%$ with successive reductions during the period from 2009 and early 2014, thus gave way to the depreciation of monetary. In this way, it was aimed to alleviate the negative outcomes of the economic recession.

CBRT announced at the beginning of 2014 that it would implement monetary tightening policy in order to prevent the negative effects on inflation and macroeconomic stability and to achieve price stability due to the significant depreciation of Money and a remarkable increase in risk Premium. Thus, it increased policy interest rate from $4.50 \%$ to $10 \%$. 
Such policy changes can achieve the designated goals if the mechanisms of transfer into reel economy functions effectively. As suggested by Houghton and Iglesias (2012), when the Central Bank changes policy interest rate, commercial banks are expected to react so as to impose the costs of this change on credit and deposit interest rates. If there is a long-term relationship between the policy interest rate controlled by the Central Bank retail rates, monetary policy comes to the fore (Haughton \&Iglesias, 2012).

\section{Literature Review}

The previous studies on the impact of monetary policy announcements by the Central Bank on market interest rates are mainly about monetary policy decisions and the measurement of the reaction of the market interest rates to these decisions with volatility. According to Blinder (2008), focusing on volatility is related with whether the Central Bank serve new information to the markets or not. Some researches done in developing countries, provision of new information by Central Bank is regarded as a part of the prevention function of the undesired volatilities in markets (Fiser \& Horvath, 2010; Goyal \& Arora, 2012).

Hartmann et al. (2001) have analyzed the volatility and dissemination effects of monetary policy announcements of European Central Bank (ECB). According to the results of the analysis, it was found that during the days when the monetary policy announcements were done by the European Central Bank, volatilite in overnight interest rates increased. Bartolini et al. (2002), Bartolini and Prati (2003), and Prati et al. (2003) concluded that there is a close relationship between monetary policy transactions and overnight interest rates in USA, Euro region and G7 countries. Bartolini and Prati (2003) suggest that short term interest rates volatilities reflect the relationship between Central Banks policy differences and interest rates.

Jochen et al. (2005) investigated the effect of macroeconomic announcements on emerging bond market movements, and concluded all macroeconomic announcements have an impact on market interest rate volatilities.

Ghosh and Bhattacharyya (2009) found that expansionary monetary policy decrease the interest rates volatility. In addition to this, the estimates imply that cash reserve rate changes also decrease the volatility on interest rates, repo and reverse repo interest rates monetary policy instruments have both increasing and decreasing effect on interest rates volatilities.

According to Leith (2009), monetary policy instruments can both decrease and increase interest rates volatilities. The empirical results of the study indicate that the effect of monetary policy changes on overnight interest rates market volatilities is weak. Moreover, it was found that monetary policy announcements have a strong effect on interest rates volatilities up to one month.

Soylu et al. (2014) investigated the impact of Central Bank interest announcements on spot and futures markets, and the results emphasized that interest decisions have different effects on analyzed variables when distinguished as increase or decrease. 


\section{Data Set and Method}

In this study, the effects of CBRT policy interest announcements on interbank interest rate, weighted average deposit interest rates (up to 1 month, 3 months, 6 months, 1 year). In this regard, monthly data about the period between January 2011 and October 2015 obtained from CBRT EDDS databases were used since interbank interest rate data could be obtained as of January 2011 period. The policy interest announcements were compiled based on interest announcements done by Monetary Policy Committee (Press Release about interest rates).

The volatility relationship between monetary policy and monetary policy announcements' interest rates were estimated using the the Generalised Autoregressive Conditional Heteroskedasticity (GARCH) model which was recommended by Engle (1982) and Bollerslev (1986) for its usefulness to get a rather flat-tailed nature compared to normal distribution and to detect the presence of unstable volatilities in time. GARCH model is also accepted as a model useful in modelling the dynamic series with high frequency. On the other hand, the GARCH $(1,1)$ model is based on its attribute of parsimony and its capacity to outperform most other models as shown by White (2000) and Hansen (2001).

In GARCH model, conditional variance is defined as a function of the terms of connection in series and moving average, where the conditional variance is transformed into an autoregressive (AR) moving average (MA)-ARMA process. In the model, there are also the delays of the conditional variance. In the present study, monetary policy announcements effect on the interest rates volatilities were tested via GARCH $(1,1)$ model, as given in equations (1), (2) and (3) below.

$$
\begin{gathered}
\mathrm{Y}=\varphi_{0}+\varphi_{1} \mathrm{Y}_{\mathrm{t}-1}+\varepsilon_{\mathrm{t}} \\
\varepsilon \mathrm{t}_{-1} / \psi_{\mathrm{t}-1} \sim \mathrm{N}\left(0, \mathrm{~h}_{\mathrm{t}}\right) \\
\mathrm{ht}=\alpha^{*} 0+\beta_{\mathrm{i}}^{*} \varepsilon^{2}+\beta_{\mathrm{j}}^{*} \mathrm{~h}_{\mathrm{t}-1}+\tau_{\mathrm{f}} * \mathrm{D}_{\mathrm{f}}
\end{gathered}
$$

In the model above, the dependent variable is interest rates, while the independent variable is the dummy variable of monetary policy announcements, which was given the value of either 1 in case there is a change in monetary policy announcements or 0 in case of no change. The dummy variables produced to explain the changes in monetary policy announcements are as follows: policy interest increase (up), policy interest kept fixed (fix) and policy interest decrease (down). Moreover, in equation (3) $\tau_{\mathrm{f}}{ }^{*}$ stands for volatility changes, while $\beta \mathrm{j}^{*}$ stands for the long terms effects on volatility.

\section{Results}

In analyses based on time-series, non-stationary of series produces unreliable results among variables. Therefore, first the stationary of the series were tested using two of the most common methods, Augmented Dickey Fuller (ADF) (1981) and Phillips-Peron (PP) (1988) unit square tests were used, the results of which were given in Appendix 1. According to the test results, interbank monetary markets interest rate (interbank) were stationary by taking their first differences since they were not stable at levels of up to 1 month deposit interest rate, up to 3 months deposit interest rate, up to 6 months deposit interest rate, and up to 1 year deposit interest rate. The stationary levels of these variables were considered as I(1). 
The descriptive statistics about the variables were analyzed before the implementation of GARCH model, which were presented in Table 1.

Table 1. Descriptive statistics on variables

\begin{tabular}{|l|l|l|l|l|l|}
\hline & Interbank & Up to 1 Month & Up to 3 Months & Up to 6 Months & Up to 1 Year \\
\hline Mean & 0.000741 & 0.000514 & 0.000584 & 0.000389 & 0.000344 \\
\hline Std. Dev. & 0.009456 & 0.004432 & 0.004447 & 0.003696 & 0.002479 \\
\hline Skewness & 0.629180 & 0.536770 & 0.622087 & 0.418285 & -0.888373 \\
\hline Kurtosis & 5.107144 & 3.063947 & 3.415697 & 3.080199 & 5.097605 \\
\hline
\end{tabular}

According to the descriptive statistics in Table 1, mean income and standard deviation values are around zero for the variables. The skewness values around zero indicates a symmetrical distribution of the variables. The kurtosis values above 3 refer a rather flat-tailed distribution compared to normal distribution.

At the next stage, the different GARCH $(1,1)$ specifications attempt to investigate whether the CBRT's monetary policy decisions have an impact on market interest rates and empirical results reported in Table 2, columns 1 through 5.

Table 2. The impact of CBRT interest announcements on interest rates: results of GARCH $(1,1)$ Model

\begin{tabular}{|c|c|c|c|c|c|c|c|c|c|c|}
\hline \multicolumn{11}{|c|}{$\mathrm{ht}=\alpha^{*} 0+\beta 1 * \varepsilon_{\mathrm{t}-1}^{2}+$} \\
\hline & \multicolumn{2}{|c|}{1} & \multicolumn{2}{|c|}{2} & \multicolumn{2}{|c|}{3} & \multicolumn{2}{|c|}{4} & \multicolumn{2}{|c|}{5} \\
\hline \multirow[t]{2}{*}{ Variables } & \multicolumn{2}{|c|}{$\begin{array}{l}\text { Interbank monetary } \\
\text { markets interest rate }\end{array}$} & \multicolumn{2}{|c|}{$\begin{array}{l}\text { Weighted average } \\
\text { deposit interest rate up } \\
\text { to } 1 \text { month }\end{array}$} & \multicolumn{2}{|c|}{$\begin{array}{c}\text { Weighted average } \\
\text { deposit interest rate up } \\
\text { to } 3 \text { months }\end{array}$} & \multicolumn{2}{|c|}{$\begin{array}{c}\text { Weighted average } \\
\text { deposit interest rate up } \\
\text { to } 6 \text { months }\end{array}$} & \multicolumn{2}{|c|}{$\begin{array}{c}\text { Weighted average } \\
\text { deposit interest rate up } \\
\text { to } 1 \text { year }\end{array}$} \\
\hline & $\begin{array}{l}\boldsymbol{\beta}_{2}{ }^{*} \\
\text { interbank }\end{array}$ & $\tau_{\mathbf{f} \text { interbank }}^{*}$ & $\begin{array}{l}\boldsymbol{\beta}_{2}{ }^{*} \text { up to } 1 \\
\text { month }\end{array}$ & $\begin{array}{l}\tau \text { f } \\
\text { month }\end{array}$ & $\begin{array}{l}\boldsymbol{\beta}_{2}{ }^{*} \text { up to } 3 \\
\text { months }\end{array}$ & $\begin{array}{l}\tau_{\mathrm{f}}^{*} \text { up to } 3 \\
\text { months }\end{array}$ & $\begin{array}{l}\beta_{2}{ }^{*} \text { up to } 6 \\
\text { months }\end{array}$ & $\begin{array}{l}\tau_{\mathrm{f}}^{*} \text { up to } 6 \\
\text { months }\end{array}$ & $\begin{array}{l}\boldsymbol{\beta}_{2}{ }^{*} \text { up to } 1 \\
\text { year }\end{array}$ & $\begin{array}{l}\tau_{\mathrm{f}}^{*} \text { up to } 1 \\
\text { year }\end{array}$ \\
\hline $\mathbf{U P}$ & $\begin{array}{l}0.494 \\
(8.67)^{*}\end{array}$ & $\begin{array}{l}-0.009841 \\
(-5.33)^{*}\end{array}$ & $\begin{array}{l}0.88 \\
(4.26)^{*}\end{array}$ & $\begin{array}{l}0.012362 \\
(2.24)^{* *}\end{array}$ & $\begin{array}{l}0.94 \\
(10.72)^{*}\end{array}$ & $\begin{array}{l}-0.007535 \\
(-6.33)^{*}\end{array}$ & $\begin{array}{l}0.64 \\
(2.20)^{* *}\end{array}$ & $\begin{array}{l}-0.000575 \\
(-0.30)\end{array}$ & $\begin{array}{l}0.144224 \\
(-2.49)^{* *}\end{array}$ & $\begin{array}{l}-0.001493 \\
(-0.79)\end{array}$ \\
\hline FIX & $\begin{array}{l}0.20 \\
(8.67)^{*}\end{array}$ & $\begin{array}{l}0.004119 \\
(3.03)^{*}\end{array}$ & $\begin{array}{l}0.64 \\
(1.94)^{* * * *}\end{array}$ & $\begin{array}{l}0.002592 \\
(1.70)^{* * *}\end{array}$ & $\begin{array}{l}0.76 \\
(1.68)^{* * *}\end{array}$ & $\begin{array}{l}0.002068 \\
(1.88)^{* *}\end{array}$ & $\begin{array}{l}0.94 \\
(8.52)^{*}\end{array}$ & $\begin{array}{l}0.001488 \\
(2.32)^{* *}\end{array}$ & $\begin{array}{l}0.482047 \\
(1.18)\end{array}$ & $\begin{array}{l}0.001111 \\
(2.38)^{* *}\end{array}$ \\
\hline DOWN & $\begin{array}{l}0.83 \\
(7.32)^{*}\end{array}$ & $\begin{array}{l}-0.000688 \\
(-0.17)\end{array}$ & $\begin{array}{l}0.86 \\
(9.29)^{*}\end{array}$ & $\begin{array}{l}-0.005112 \\
(-3.84)^{*}\end{array}$ & $\begin{array}{l}0.477022 \\
(3.24)^{*}\end{array}$ & $\begin{array}{l}-0.001538 \\
(-1.31)\end{array}$ & $\begin{array}{l}0.98 \\
(7.05)^{*}\end{array}$ & $\begin{array}{l}-0.001823 \\
(-2.08)^{* *}\end{array}$ & $\begin{array}{l}0.493402 \\
(0.93)\end{array}$ & $\begin{array}{l}-0.000930 \\
(-1.55)\end{array}$ \\
\hline
\end{tabular}

Note: ( ) indicates z statistics value, $* * *$ and $* * *$ refer to $1 \%, 5 \%$, and $10 \%$ significance levels, respectively.

The column 1 in Table 2 shows the volatility impact results of monetary policy announcements on interbank markets interest rate through GARCH $(1,1)$ model. According to the $\tau_{\mathrm{f}}{ }^{*}$ interbank coefficient, which indicates the volatility of the Monetary policy announcements on interbank monetary markets interest rate, the announcements regarding the increase of policy interest have a negative volatility effect on interbank monetary markets interest rates. This result suggests that contractionary monetary policy reduces the volatility in interbank 
monetary markets. Central Bank's announcements about keeping the policy interest fixed, on the other hand, have a positive volatility effect on interbank monetary markets interest rates. This finding means that announcements in which monetary policy was kept fixed increase the volatility in interbank monetary markets. On the other hand, the announcements regarding the decrease of policy interest has a negative but insignificant volatility effect on interbank monetary markets interest rates. It needs to be noted that the announcements regarding the increase of policy interest by the Central Bank have an even bigger effect on interbank interest rate movements.

Since the $\beta_{2}{ }^{*}$ interbank coefficient, which shows the long term effects on volatility, was found very high (0.83) indicating the volatility stability in policy interest decrease announcements, it is understood that the effects of such policy shocks will disappear in a long time. On the contrary, shocks of policy interest increase and fixed do not cause lasting effects on interbank interest rates volatility (the coefficients are 0.20 and 0.49 , respectively). The volatility permanence time can be calculated with the half-life of a shock formulated as $\mathrm{HL}=\log (0.5)$ / $\log \left(\beta_{2}{ }^{*}\right)$ (Çiçek, 2010, p. 24). In the present study the volatility permanence time was estimated as 0.97 for announcements about policy interest increases, as 0.43 when the policy interest is notified to be fixed, and as 3.75 in case of a policy interest decrease. Accordingly, policy interest increase announcements volatility shocks last for about 1 month, while they last for about 15 days in case policy interests are fixed, and for about 4 months in case of policy interest decrease announcements. These results imply that the long term effect of expansionary monetary policy on interbank monetary market volatilities are stronger.

The $2^{\text {nd }}$ column presents the results regarding the $\operatorname{GARCH}(1,1)$ model volatility effect of monetary policy announcements on the weighted average deposit interest rates by banks up to 1 month. According to $\tau_{\mathrm{f}}{ }^{*}$ up to 1 month coefficient which reflects the volatility changes of monetary policy announcements on weighted average deposit interest rates up to 1 month, the policy interest decrease announcements have a negative volatility effect on deposit interest rates up to one month. This finding indicates that expansionary monetary policy decreases volatility on the deposit interest rates up to one month. Central Bank's announcements regarding policy interest increase and stabilization have a positive volatility effect on deposit interest rates up to one month. This finding means that contractionary monetary policy and decisions to keep the monetary policy fixed increase the volatility in deposit interest rates up to 1 month. According to the results obtained from GARCH $(1,1)$ model, announcements by the Central Bank regarding an increase in policy interest have a much stronger effect on deposit interest rate movements up to 1 month.

The $\beta_{2}{ }^{*}$ up to 1 month coefficient, which refers to the long-term effects on volatility, indicates that it takes long time for the policy shocks to disappear, since in policy interest increase and decrease announcements the degree of volatility permanence was found very high (the coeficients were 0.88 and 0.86 respectively). The volatility permanence time of monetary policy announcements is 5.42 for policy interest increase announcements, and 1.55 when policy interest stays fixed, and 4.59 for policy interest decrease. Accordingly, policy interest increase announcements volatility shocks last for about 5,4 months, while they last for about 1,6 month in case policy interests stay fixed and about 4,6 months after policy interest 
decrease announcements. These findings suggest that the long term effects of contractionary monetary policy on deposit interest rate volatilities up to one month is stronger.

According to the $\tau_{\mathrm{f}}{ }^{*}$ up to 3 months coefficient in column 3 , which reflects the volatility changes of monetary policy announcements on weighted average deposit interest rates up to 3 months opened by the banks, the policy interest increase announcements have a negative volatility effect on deposit interest rates up to 3 months. This finding suggests that contractionary monetary policy decreases the volatility on deposit interest rates up to 3 months. Central Bank's announcements regarding the fixation of policy interest have a positive volatility effect on deposit interest rates up to 3 months. This finding suggests that the decisions about fixing the monetary policy increase volatility in deposit interest rates up to 3 months. On the other hand, although policy interest decrease announcements have a negative volatility effect on deposit interest rates up to 3 months, the results were found to be statistically insignificant. According to these results decisions regarding the policy interest increase have much stronger effect on deposit interest rate movements up to 3 months.

According to the $\beta_{2}{ }^{*}$ up to 3 months coefficient, which shows the long term effect on volatility, the degree of volatility permanence in policy interest increase announcements were found very high. In this respect, it is understood that it takes a long time for the policy interest increase shock effects to disappear. The volatility permanence time of the monetary policy announcements was calculated as 11.23 for policy interest increase announcements, while it is 2.52 in case the policy interest stays fixed and 0.91 for policy interest decrease. Accordingly, policy interest increase announcements volatility shocks last for about 11 months, while they last for about 2,5 months in case policy interest stays fixed, and about 27 days in case of policy interest decrease announcements. These findings imply that the long terms effects of contractionary monetary policy on deposit interest rate volatilities up to 3 months are stronger.

The 4th column presents the results regarding the volatility effect of monetary policy announcements on the weighted average deposit interest rates by banks up to 6 months. According to $\tau_{\mathrm{f}}{ }^{*}$ up to 6 months coefficient, the policy interest decrease announcements have a negative volatility effect on deposit interest rates up to 6 month. This finding indicates that expansionary monetary policy decreases volatility on the deposit interest rates up to 6 months. Central Bank's announcements regarding policy interest stabilization have a positive volatility effect on deposit interest rates up to 6 months. This finding means that decisions to keep the monetary policy fixed increase the volatility in deposit interest rates up to 6 months. On the other hand, although policy interest decrease announcements have a negative volatility effect on deposit interest rates up to 6 months, the results were found to be statistically insignificant. According to the results, announcements by the Central Bank regarding a decrease in policy interest have a much stronger effect on deposit interest rate movements up to 6 months.

The $\beta_{2}{ }^{*}$ up to 6 months coefficient, which refers to the long-term effects on volatility, indicates that it takes long time for the policy shocks to disappear, since in policy interest increase and decrease announcements the degree of volatility permanence was found very high (the 
coefficients were 0.94 and 0.98 respectively). The volatility permanence time of monetary policy announcements is 1.55 for policy interest increase announcements, and 11.57 when policy interest stays fixed, and 37.62 for policy interest decrease. Accordingly, policy interest increase announcements volatility shocks last for about 1,5 months, while they last for about 1 year month case policy interests stay fixed and about 3 years after policy interest decrease announcements. These findings suggest that the long term effects of contractionary monetary policy on deposit interest rate volatilities up to 6 months is stronger.

According to the $\tau_{\mathrm{f}}{ }^{*}$ up to 1 year coefficient in column 5, which reflects the volatility changes of monetary policy announcements on weighted average deposit interest rates up to 1 year opened by the banks, the policy interest increase announcements have a positive volatility effect on deposit interest rates up to 1 year. This finding suggests that policy announcements regarding the stabilization of monetary policy increases the volatility on deposit interest rates up to 1 year. On the other hand, although policy interest decrease and increase announcements have a negative volatility effect on deposit interest rates up to 1 year, the results were found to be statistically insignificant. The $\beta_{2}{ }^{*}$ up to 1 year coefficient, which refers to the long-term effects on volatility, was found statistically insignificant in announcements regarding the policy interest decrease and fixed. Policy interest increase shocks, on the other hand, do not cause any lasting effects on deposit interest rates volatility up to 1 year.

\section{Conclusion}

Central Bank's changes in monetary policy interest decisions have an important value in terms of their capacity to affect market and bank interest rates and an active monetary policy. In the present study, it was investigated whether the interest announcements of interest decisions taken by the monetary policy commission are perceived as new information (news) by the monetary market, and cause a different reactions nor not using the monthly data for the 2011:1-2015:10 period in Turkey through GARCH model. The impact of interest announcements by CBRT on volatility was tested for three alternative scenarios: in case of an increase in policy interest rate, in case of a decrease in policy interest rate, and in case of no change in policy interest. Thus, it was aimed to determine the reaction of market interest rates in response to monetary policy announcements.

According to the estimations, policy interest increase announcements had a decreasing effect on interbank monetary market interest rate and up to 3 month deposit interest rate, but increased the volatility on deposit interest rate up to 1 month. However, it did not have an effect on deposit interest rate up to 6 months and deposit interest rates up to one year. This result indicates that policy interest increase decisions causes a stronger reaction on short term dated interest rates. In case of up to 1 month regarding the stabilization of policy interest, it increases the volatility on interbank monetary market interest rate and deposit interest rates (up to 1 month, 3 months, 6 months, and 1 year). This finding implies that the decisions regarding the change of policy interest is perceived ambiguity by the monetary markets and increase the reaction interest rates show in response to monetary policy decisions.

Policy interest decrease announcements, on the other hand, decreases the volatilities on deposite interest rate up to 1 month and deposit interest rate up to 6 months. According to this 
finding, Central Bank interest decrease announcements decrease significantly the volatilities on deposit interest rate up to 1 year and deposit interest rate up to 6 months and prevent the undesired interest rate movements. Interbank monetary market interest rate do not have any effect on deposit interest rate up to 3 months and deposit interest rates up to 1 year.

The findings of this study indicate that contractionary monetary policy announcements have both decreasing and increasing effect on the volatility of the interest rates. It was also found that while expansionary monetary policy decreases the volatility on interest rate, it increases the interest volatilities in case the monetary policy is kept fixed.

Consequently, it was concluded that as a result of the increasing transparency and communication policies accompanying the implementation of inflation targeting regime, the reactions of market interest rates in response to contractionary monetary policy and expansionary monetary policy decisions fulfill the functions of directing the markets and reduce the ambiguities. However, since it takes longer time for the aftermaths of the contractionary monetary policy and expansionary monetary policy shocks to disappear, it can be concluded that the effect of monetary policy on economy is strong but not fully active. These findings can enhance our understanding of the interaction between monetary policy announcements and market interest rates and can be used as a useful guide in making monetary policy decisions.

\section{Acknowledgement}

This study supported by Anadolu University Scientific Research Projects Commission under the Grant Nr. 1603E096.

\section{References}

Akay, H. K., \& Nargelecekenler M. (2009). Para politikası Şokları Hisse Senedi Fiyatlarını Etkiler mi? Türkiye Örneği. Marmara Üniversitesi İIBF Dergisi, 27(2), 129-152.

Bartolini, L., \& Prati, A. (2003). The execution of Monetary Policy: a Tale of Two Central Banks. Economic Policy, 18(37), 435-67. https://doi.org/10.1111/1468-0327.00112_1

Bartolini, L., Bertola, G., \& Prati, A. (2002). Day-to-day Monetary Policy and the Volatility of the Federal Funds Interest Rate. Journal of Money Credit and Banking, 34(1), 137-59. https://doi.org/10.1353/mcb.2002.0025

Blinder, A., Ehrmann, M., Fratzscher, M., De Haan, J., \& Jansen, D.-J. (2008). Central Bank Communication and Monetary Policy: A Survey of Theory and Evidence. CEPS Working Paper No. 161. https://doi.org/10.3386/w13932

Bollerslev, T. (1986). Generalized Autoregressive Conditional Heteroscedasticity. Journal of Econometrics, 31(February), 307-327. https://doi.org/10.1016/0304-4076(86)90063-1

CBRT (2004). 2005 Y1lında Para ve Kur Politikas1. [Online] Available: http://www.tcmb.gov.tr/wps/wcm/connect/3825db04-42bb-4844-8b6944b645b81245/DUY20 0459.pdf?MOD=AJPERES\&CACHEID=ROOTWORKSPACE3825db04-42bb-4844-8b69-4 4b645b81245 (October 5, 2016) 
CBRT (2013). Parasal Aktarim Mekanizmasi. [Online] Available: http://www.tcmb.gov.tr/wps/wcm/connect/8cdd0f38-142f-493b-b489-bdc0111491bb/Parasal Aktarim.pdf?MOD=AJPERES (October 5, 2016)

Cicek M. (2010). Türkiye'de Faiz, Döviz ve Borsa: Fiyat ve Oynaklık Yayılma Etkileri.Ankara Üniversitesi SBF Dergisi, 65(2), 1-28.

https://doi.org/10.1501/SBFder_0000002170

Dickey, D., \& Fuller, W. A. (1981). Likelihood Ratio Statistics for Autoregressive Time Series with A Unit Root. Econometrica, 49(4), 1057-1072. https://doi.org/10.2307/1912517

Engle, R. F. (1982). Autoregressive Conditional Heteroscedasdicity with Estimates of the Variance of United Kingdom Inflation. Econometrica, 50(4), 987-1007.

https://doi.org/10.2307/1912773

Fiser, R., \& Horvath, R. (2010). Central Bank communication and exchange rate volatility: a GARCH analysis. Macroeconomics and Finance in Emerging Market Economies, 3(1), 25-31. https://doi.org/10.1080/17520840903498099

Ghosh, S., \& Bhattacharyya, I. (2009). Spread, Volatility and Monetary Policy: Empirical Evidence From the Indian Overnight Money Market. Macroeconomics and Finance in Emerging Market Economies, 2(2), 257-277. https://doi.org/10.1080/17520840903076622

Goyal, A., \& Arora, S. (2012). The Indian exchange rate and Central Bank Action: an EGARCH Analysis. Journal of Asian Economics, 23(1), 60-72.

https://doi.org/10.1016/j.asieco.2011.09.001

Hansen, P. R. (2001). An Unbiased and Powerful Test for Superior Predictive Ability. [Online] Available: http://chico.pstc.brown.edu/ phansen (June 12, 2016)

Hartmann, P., Manna, M., \& A. Manzanares, A. (2001). The Microstructure of the Euro Money Market. Journal of International Money and Finance, 20(6), 895-948.

https://doi.org/10.1016/S0261-5606(01)00029-8

Houghton, A. Y., \& Iglesias, M. (2012). Interest Rate Volatility, Asymmetric Interest Rates Pass Through and the Monetary Transmission Mechanism in the Caribbean Compared to US and Asia. Economic Modelling, 29(6), 2071-2080.

https://doi.org/10.1016/j.econmod.2012.06.034

Jochen, R. A., Geoffrey, J. B., \& Natalia, T. T. (2005). The Impact of Macroeconomic Announcements on Emerging Market Bonds. IMF Working Paper, 05/83, 1-31. [Online] Available:

https://www.imf.org/ /media/Websites/IMF/imported-full-text-pdf/external/pubs/ft/wp/2005/ _wp0583.ashx(May 31, 2016)

Leith, D. (2009). The Effect of Monetary Policy on Private Money Market Rates in Jamaica: An Empirical Microstructure Study. [Online] Available: http://www.boj.org.jm/uploads/pdf/papers_pamphlets/papers_pamphlets_The_Effect_of_Mon etary_Policy_on_Private_Money_Market_Rates_in_Jamaica_An_Empirical_Microstructure 
_Study.pdf (May 17, 2016)

Manna, M., Pill, H., \& Quiros, G. (2001). The Eurosystem's Operational Framework in the Context of theECB's Monetary Policy Strategy. International Finance, 4(1), 65-99.

https://doi.org/10.1111/1468-2362.00066

Phillips, P. C. B., \& Peron, P. (1988). Testing for a Unit Root in Time Series Regression. Biomètrika, 75(2), 336-346. https://doi.org/10.1093/biomet/75.2.335

Prati, A., Bartolini, L., \& Bertola, G. (2003). The Overnight Interbank Market: Evidence from the G-7 and the Euro Zone. Journal of Banking and Finance, 27(10), 2045-83.

https://doi.org/10.1016/S0378-4266(02)00320-5

Soylu, N., Korkmaz, T., \& Cevik, İ. E. (2014). Merkez Bankası Faiz Duyurularının Finansal Piyasalara Etkisi. Business and Economics Research Journal, 5(4), 89-118.

White, H. (2000). A Reality Check for Data Snooping. Econometrica, 68(5), 1097-126. https://doi.org/10.1111/1468-0262.00152

\section{Appendix}

\section{Appendix -1: Results of ADF and PP Unit Root Test Statistics}

\begin{tabular}{|l|l|l|l|l|l|l|l|l|}
\hline Değişkenler & ADF & \%1 level & \%5 Level & \%10 level & PP & \%1 level & \%5 level & \%10 level \\
\hline Interbank & -2.25 & -3.55 & -2.91 & -2.59 & -1.85 & -3.55 & -2.91 & -2.59 \\
\hline$\Delta$ Interbank & -5.64 & -3.55 & -2.91 & -2.59 & -5.45 & -3.55 & -2.91 & -2.59 \\
\hline Up to 1 Month & -1.91 & -3.55 & -2.91 & -2.59 & -1.38 & -3.55 & -2.91 & -2.59 \\
\hline$\Delta$ Up to 1 Month & -5.02 & -3.55 & -2.91 & -2.59 & -5.00 & -3.55 & -2.91 & -2.59 \\
\hline Up to 3 Months & -1.65 & -3.55 & -2.91 & -2.59 & -1.45 & -3.55 & -2.91 & -2.59 \\
\hline$\Delta$ Up to 3Months & -5.20 & -3.55 & -2.91 & -2.59 & -3.22 & -3.55 & -2.91 & -2.59 \\
\hline Up to 6 Months & -2.19 & -3.55 & -2.91 & -2.59 & -1.67 & -3.55 & -2.91 & -2.59 \\
\hline$\Delta$ Up to6 Months & -4.67 & -3.55 & -2.91 & -2.59 & -3.20 & -3.55 & -2.91 & -2.59 \\
\hline Up to 1 Year & -2.88 & -3.55 & -2.91 & -2.59 & -1.90 & -3.55 & -2.91 & -2.59 \\
\hline Up to 1 Year & -3.05 & -3.55 & -2.91 & -2.59 & -3.21 & -3.55 & -2.91 & -2.59 \\
\hline
\end{tabular}

\section{Copyright Disclaimer}

Copyright for this article is retained by the author(s), with first publication rights granted to the journal.

This is an open-access article distributed under the terms and conditions of the Creative Commons Attribution license (http://creativecommons.org/licenses/by/3.0/). 